\title{
REKONSTRUKCIJA OZEMELJ \\ PRAZGODOVINSKIH SKUPNOSTI NA \\ PROSTORU SEVERNEGA IN SREDNJEGA \\ VELEBITA Z UPORABO GIS-OV
}

\author{
dr.Vedrana Glavaš*,Aleš Grlj**, mag. geog. \\ * Oddelek za arheologijo, Univerza v Zadru \\ Obala Kralja Petra Krešimira IV. 2, HR-23000 Zadar \\ ** Harpha Sea, d. o. o. Koper \\ Čevljarska 8, SI-6000 Koper \\ e-pošta:vedrana.glavas@gmail.com, ales@harphasea.si \\ Izvirni znanstveni članek \\ COBISS 1.01 \\ DOI: $10.4312 /$ dela.45.4.65-81
}

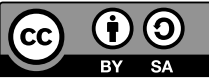

\section{Izvleček}

Prispevek obravnava metodo rekonstrukcije ozemelj prazgodovinskih skupnosti z uporabo geografskih informacijskih sistemov (GIS-ov). Osredotočili smo se na železnodobne skupnosti severnega in srednjega Velebita na Hrvaškem, vendar je materialnih ostankov, ki bi neposredno dokazovali njihov obseg, zelo malo. Ozemlja predantičnih skupnosti smo modelirali z uporabo GIS-a glede na reliefne značilnosti in časovno oddaljenost dveh ur hoje od osrednjih gradišč z uporabo Toblerjeve enačbe.

Ključne besede: železna doba, gradišča, gospodarsko zaledje, GIS, Velebit

\section{GIS BASED RECONSTRUCTION OF THE PREHISTORIC COMMUNITIES' TERRITORIES OF THE NORTHERN AND CENTRAL VELEBIT MOUNTAIN}

\begin{abstract}
A method for reconstructing prehistoric territories implementing the geographic information systems (GIS) is presented in this article. We focused our research on Iron Age communities of northern and central Velebit Mountain (Croatia), but traces of their territorial extent are very scarce or nonexistent. Territories of the communities in question were modeled using GIS according to the relief characteristics and the time scale of a two-hour walk from the central hill forts using Tobler's Hiking Equation.
\end{abstract}

Key words: Iron Age, hill forts, site catchment, GIS, Velebit Mountain 


\section{UVOD}

Eno večjih težav v arheoloških in zgodovinskih raziskavah prazgodovinskih skupnosti predstavljajo rekonstrukcije obsega njihovih ozemelj in meja zaradi pomanjkljivih materialnih in pisnih podatkov. Za razliko od rekonstrukcij ozemelj antičnih in srednjeveških skupnosti rekonstrukcije prazgodovinskih otežuje majhno število ali celo neobstoj podatkov o razmejitvah, ki bi neposredno nakazovali na označevanje meja ozemlja. Prvi pristopi definiranja obsega ozemelj so pogosto temeljili na subjektivni interpretaciji raziskovalcev, ki so rekonstrukcije izdelovali na podlagi razporeditve arheoloških najdišč ali delnih dokazov o razmejitvah (Čače, 2006; Dubolnić, 2007). Zadnjih dvajset let so se, vzporedno z razvojem računalniških orodij in njihovo uporabo v arheologiji, pojavili novi pristopi raziskovanja teritorialnosti (Ducke, Kroefges, 2008) z GIS-i.

Namen raziskave je rekonstrukcija ozemelj prazgodovinskih železnodobnih skupnosti na območju severnega in srednjega Velebita na Hrvaškem. Območje raziskave smo omejili na prostor med prelazoma Vratnik $(698 \mathrm{~m})$ in Baške oštarije (920 m). Raziskovalno vprašanje, ki ga izpostavljamo, se nanaša na metodo rekonstrukcije ozemlja določene

Slika 1: Lokacija proučevanega območja.

Figure 1: Study area location.

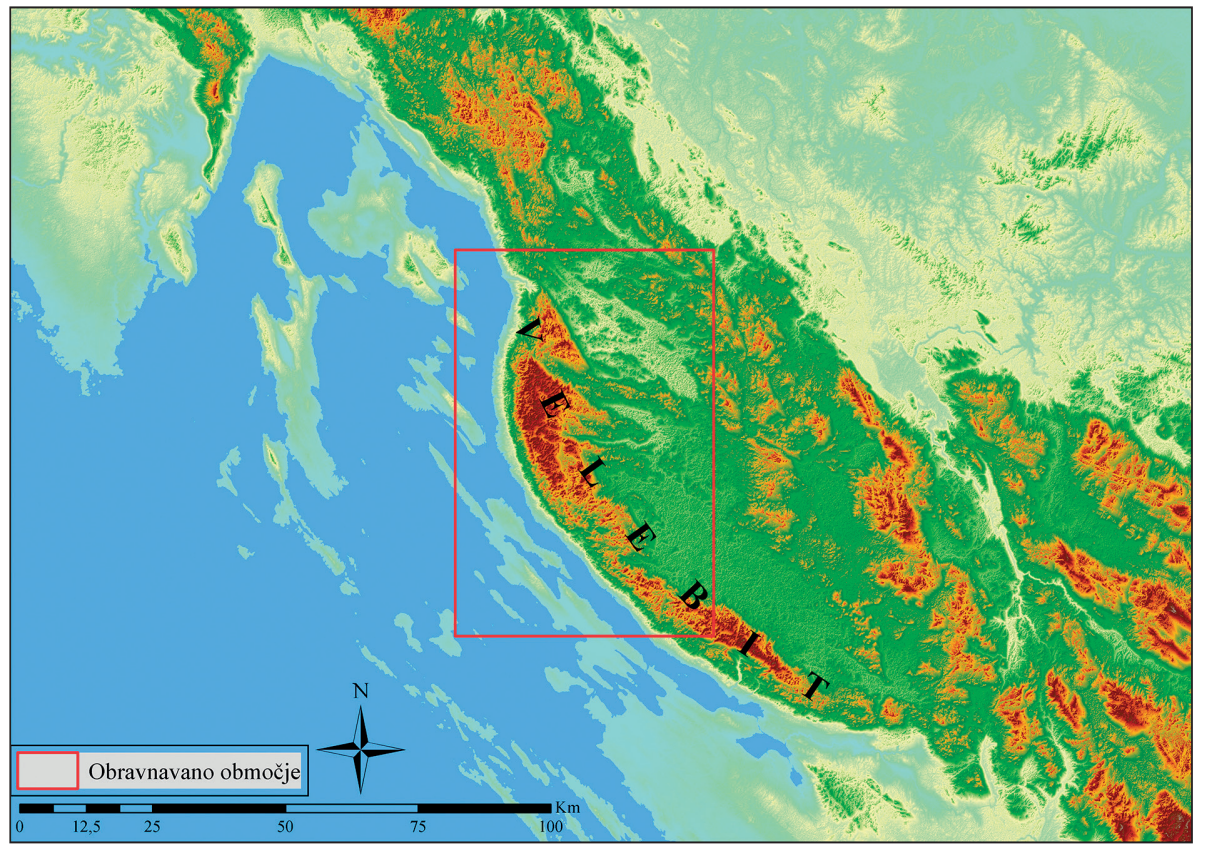

Vir/Source: NASA, JPL, 2009.

ASTER GDEM je proizvod NASA in METI/ASTER GDEM is a product of NASA and METI. 
prazgodovinske skupnosti proučevanega območja, s katerega nimamo dovolj snovnih dokazov o razmejitvi.

Glede na to, da je gibanje ljudi v prostoru eden od osnovnih parametrov za oblikovanje ozemlja, smo ga uporabili kot poglavitno spremenljivko, ki določa površino in obliko ozemlja. Površje proučevanega območja Velebita je izrazito raznoliko in razčlenjeno ter ne dovoljuje homogene prehodnosti, zato smo dinamiko gibanja $\mathrm{v}$ prostoru modelirali zlasti glede na reliefne značilnosti. V ta namen smo uporabili GIS ter digitalni model višin (DMV) za izračun časa, potrebnega za potovanje od posameznega gradišča (navedena so v preglednici 1) do vsake celice rastrskega sloja digitalnega modela višin obravnavanega območja. Pri modeliranju smo poleg analize gibanja glede na reliefne značilnosti upoštevali tudi ostale parametre, ki so ključni za rekonstrukcijo ozemelj. To so zlasti morfološke značilnosti reliefa, ki definirajo prostorske odnose med lokacijami gradišč in njihovo vidnost.

\section{PREDHODNE RAZISKAVE}

Obmorska pobočja Velebita so v starejši literaturi omenjena zlasti v kontekstu najdb posamičnih predmetov materialne kulturne dediščine (Brunšmid, 1898; 1899; 1901; Ljubić, 1880; 1889; 1891). Prvi raziskovalec železnodobne kulture Velebita je bil Ante Glavičić, ki je izvedel podrobne inventarizacije poznanih in novo odkritih arheoloških najdišč (Glavičić A., 1966; 1967-68; 1970; 1980; 1982; 1984).

Edino rekonstrukcijo je izdelal Miroslav Glavičić na primeru avtohtone peregrinske skupnosti (civitas Lopsica) iz Podvelebitskega Primorja z uporabo analize prostorske razmestitve gradišč (Glavičić M., 1997). Tudi ostale rekonstrukcije na območju Liburnije so avtorji izdelali zlasti na osnovi prostorske razporeditve najdišč in na osnovi morfoloških značilnosti pokrajine (Čače, 2007; Dubolnić, 2007), kar smo, z uporabo GIS-a, deloma izvedli tudi v naši raziskavi. Dognanja dosedanjih rekonstrukcij ozemelj večinoma izenačujejo območje mlajših, tako imenovanih peregrinskih civitates, s prazgodovinskimi železnodobnimi ozemlji (Chapman in sod., 1996; Glavičić M., 1997; Suić, 2003; Čače, 2006).

\section{UPORABLJENE METODE}

Rekonstrukcije so bile izvedene z uporabo programa ESRI ArcGIS 10.1. Osnovna podlaga za analize je bil digitalni model višin s prostorsko ločljivostjo 21 m (DGU, 2015). Izdelan je bil na osnovi točkovnih podatkov o višinah in metode interpolacije navadni kriging (ang. ordinary kriging), izvedene z navedeno programsko opremo. Podatke o gradiščih (preglednica 1), ki so bili uporabljeni v analizi, smo zbrali s pregledom strokovne literature (Glavičić A., 1966; 1967-1968; 1970; 1980; 1982; 1984; Glavičić M., 1991-1992; 1997) ter terenskim in letalskim pregledom celotnega obravnavanega območja (Glavaš, Palmer, 2013). Osnovno izhodišče za rekonstrukcijo temelji na predpostavki, da antična ozemlja ne odražajo vedno prazgodovinskega stanja. Izhajajoč iz tega smo ozemlja rekonstruirali s pomočjo analize premikanja in prostorske analize razporeditve gradišč, na katerih je bila s terenskim delom ugotovljena znatna oziroma pomembnejša aktivnost. 
Gradišča z zaznano pomembno aktivnostjo so tista, na katerih so bile na površini najdene večje količine prazgodovinske keramike, masivnejše strukture, ali vsebujejo več kulturnih plasti, kar nakazuje na prazgodovinsko poselitev. Opredelili smo šest gradišč in jih v analizah uporabili kot središča oziroma izhodišča za rekonstrukcijo (slika 4). Poleg večje količine arheoloških ostankov se ta gradišča nahajajo v bližini naravnega vira in na izhodiščih poti, ki vodijo preko Velebita.

Glavna uporabljena analiza za rekonstrukcijo ozemelj je analiza stroškovnih površin (ang. cost surface analysis), s pomočjo katere smo izračunali gospodarsko zaledje (ang. site catchment, termin je podrobno razložen v: Stančič, Gaffney, 1991; Novaković, 2003; Štular, 2006) posameznih gradišč. Gospodarsko zaledje naselja predstavlja območje, znotraj katerega prebivalci tega naselja ekonomsko izkoriščajo naravne vire. $Z$ večanjem oddaljenosti virov od naselja se zmanjšuje verjetnost izkoriščanja vira, saj z oddaljevanjem naraščajo stroški izkoriščanja oziroma potovanja proti viru in nazaj (Vita-Finzi, Higgs, 1970). Za izkoriščanje virov so se morali pripadniki skupnosti gibati v okviru svojega ozemlja na predelu od kraja bivanja do območja izkoriščanja in obratno. Viri za izkoriščanje so se torej morali nahajati v bližnji ali daljni okolici naselja znotraj gospodarskega zaledja (Vita-Finzi, Higgs, 1970).

Analiza stroškovnih površin (ang. cost surface analysis) temelji na izračunu stroška za potovanje skozi vsako celico vhodnega podatkovnega sloja, ker s premikanjem po različnih tipih površja (ravnina, gričevje ...) porabljamo različno količino energije. Skladno s tem se spreminja hitrost premikanja, ki je vezana tudi na vrsto ekonomske aktivnosti (npr. hoja za živino ali hoja proti obdelovalnim površinam), fizično stanje človeka (starost, spol), način potovanja (peš, na konju, na vozu ...), relief, prisotnost oziroma neprisotnost stez, poti, cest itd.

Gospodarsko zaledje v raziskavi obravnavanih gradišč smo opredelili na podlagi oddaljenosti, ki jo prehodimo v dveh urah, saj se po empiričnih ocenah etnoarheoloških raziskav

Slika 2: Graf anizotropnega modela za izračun hitrosti premikanja glede na naklon pobočja in smer premikanja.

Figure 2: Plot of the anisotropic speed calculating function that considers the slopes values and direction of the movement.

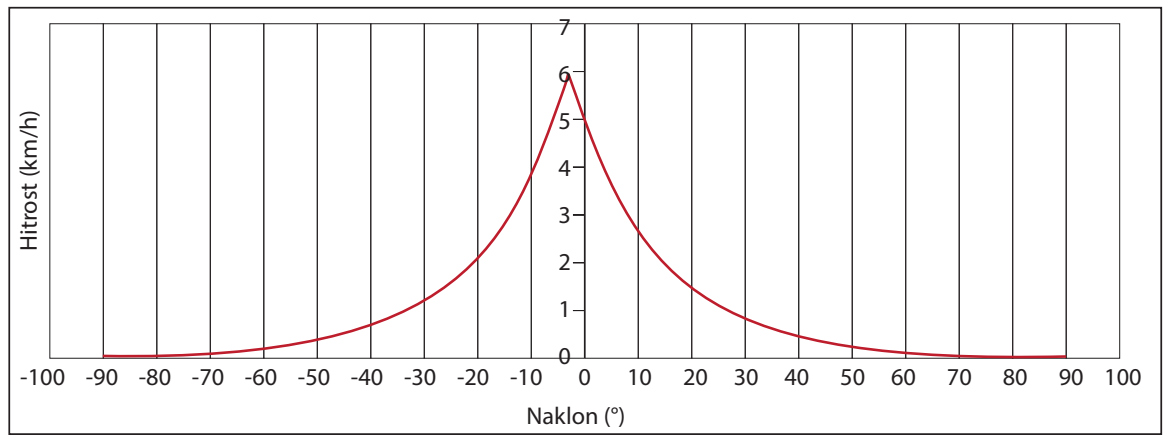

Vir/Source: prirejeno po Tobler, 1993. 
pripadniki skupnosti, ki se primarno ukvarja s poljedelstvom, vsakodnevno gibljejo v krogu 1 ure hoje od naselja, lovsko in živinorejsko usmerjene skupnosti pa se gibljejo v krogu 2 ur (Chrisholm, 1962; Bintliff, 1977). Časovna oddaljenost 2 uri hoje od gradišča je v raziskavi uporabljena kot empirična vrednost za nomadske/lovske/živinorejske skupnosti, ki so oblikovale ozemlje, ko so se gibale za domačimi in divjimi živalmi. Kljub temu, da za prostor Velebita nimamo na razpolago podatkov o premikanju ljudi in živali v bližini naselij, je bil ta model uporabljen in preizkušen na prostoru podvelebitskega Primorja, saj se je tukajšnje prebivalstvo ukvarjalo z živinorejo. Gospodarska zaledja so prikazana na zemljevidih kot izohrone na oddaljenosti dveh ur hoje od središča ozemlja.

Za izračun stroškov premikanja glede na naklon terena in oddaljenost je uporabljen anizotropen Toblerjev model, prikazan na sliki 2 (ang. Tobler's hiking equation). Anizotropija modela se odraža v dejstvu, da se hitrost premikanja navzdol, v odvisnosti od naklona, spreminja drugače kot hitrost premikanja navzgor. Iz tega izhaja, da je graf funkcije asimetričen glede na naklon $0^{\circ}$. Model se uporablja za izračun stroškov oziroma hitrosti premikanja na spremenljivem tipu terena (navzgor, navzdol, ravnina). Izdelan je bil na podlagi empiričnih podatkov o hitrosti premikanja v švicarskih Alpah (Tobler, 1993):

$$
\begin{aligned}
& W=6 e^{-3,5\left|\frac{d h}{d x}+0,05\right|} \\
& \frac{d h}{d x}=S=\tan \theta
\end{aligned}
$$

kjer je $\mathrm{W}$ hitrost hoje, dh višinska razlika med dvema sosednjima celicama vhodnega DMV, dx pa razdalja med tema dvema celicama. Koeficient zadnjih dveh spremenljivk je naklon med središčema dveh celic oziroma tangens kota $\theta$. Tan $\theta$ je rastrski podatkovni sloj naklonov pobočij $\mathrm{v}$ radianih, ki ga dobimo z matematično analizo DMV.

$\mathrm{Z}$ uporabo Toblerjeve enačbe dobimo hitrost gibanja skozi vsako celico vhodnega rastrskega sloja podatkov. Izračun prikaže vrednosti med $9,43046 \times 10^{-5} \mathrm{~km} / \mathrm{h}$ kot najmanjšo hitrost gibanja in $5,04 \mathrm{~km} / \mathrm{h}$ kot največjo hitrost. $Z$ množenjem izračunanega podatkovnega sloja $\mathrm{Z}$ vrednostjo 0,2778 vrednosti sloja pretvorimo $\mathrm{v}$ metre na sekundo. Sledi izračun časa za prehod vsake celice s hitrostjo, ki jo ta celica dovoljuje. Informacijo dobimo na tak način, da diagonalo celice (d1 na sliki 3, v našem primeru 29,6 m) delimo $\mathrm{z}$ vrednostmi v izračunanem podatkovnem sloju. Dolžina diagonale je uporabljena zato, ker se lahko preko celice premikamo tudi diagonalno ter za poenostavitev izračuna. Za natančnejši rezultat bi morali za vsako celico sloja upoštevati, ali je pri izračunu "prečkana « v smeri ene od stranic ali v smeri ene od diagonal ter uporabiti pripadajočo dolžino 21 $\mathrm{m} v$ prvem in 29,6 $\mathrm{m}$ v drugem primeru. Rezultat je rastrski sloj podatkov o trenju površja (ang. friction surface raster), ki ga lahko uporabimo v orodju za izračun stroškovnih razdalj (ang. Cost Distance) programa ArcGIS 10.1 v kombinaciji s slojem podatkov, v katerem so podane lokacije gradišč. Na tak način izračunamo kumulativni upor terena za gibanje v vseh smereh od lokacije gradišča (slika 3 ).

Na podlagi stroškovnega površja smo opredelili gospodarska zaledja gradišč. To so območja, ki so v manj kot dveh urah (v naših izračunih stroškovnega površja izraženih s 7200 sekundami) dostopna peš iz časovno najbližjega gradišča (slika 3). Celoten postopek izračuna 
Slika 3: Konceptualni model izračuna gospodarskih zaledij z uporabo programa ArcMap 10.1. Figure 3: Conceptual model of site catchment calculation using ArcMap 10.1 software.

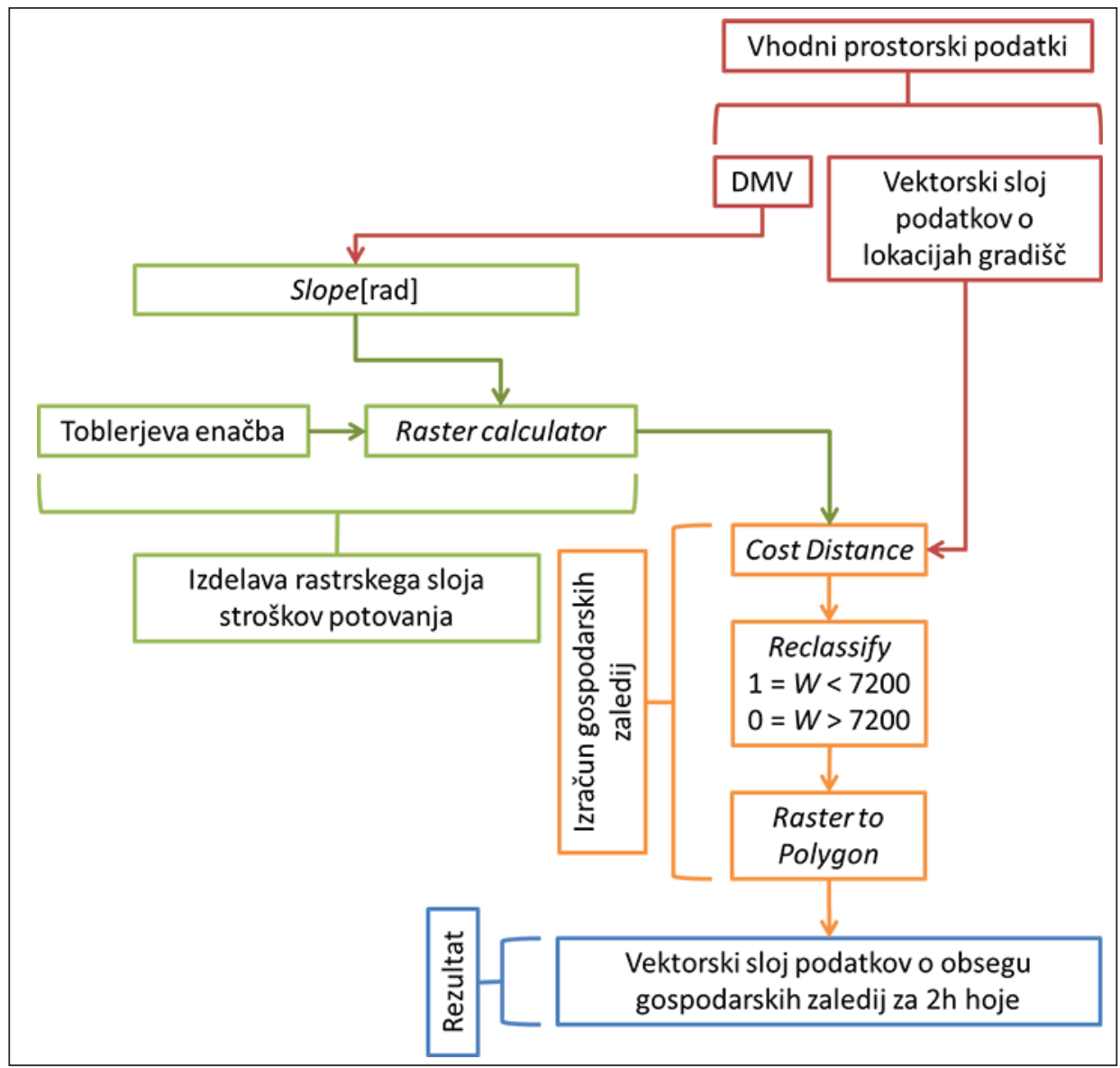

gospodarskih zaledij smo avtomatizirali z uporabo orodja ArcGIS 10.1 Model Builder in s tem skrajšali čas obdelave podatkov ter omogočili obdelavo velikih podatkovnih slojev.

Poudariti moramo, da je vrednost 2 uri hoje kot definicija obsega ozemelj v raziskavi arbitrarna in je ni mogoče jemati kot strogo določeno vrednost, ker je bilo gibanje odvisno od ekonomske dejavnosti. Pri nekaterih gospodarskih praksah, kot na primer pri transhumantni sezonski živinoreji, je čas potovanja daljši, medtem ko je pri drugih, na primer poljedeljstvu, krajši. Zaradi tega smo rezultate analize dodatno kritično ovrednotili glede na razporeditev gradišč, analizo obsega površja, vidnega z gradišč (Glavaš, 2014), migracijske koridorje (Grlj, Glavaš, 2015), oddaljenost od središčnih gradišč, geomorfološke značilnosti površja in teoretična zaledja gradišč, določena tako, da je vsaka lokacija znotraj zaledja bližje pripadajočemu gradišču kot drugim gradiščem (Thiessenovi poligoni) (ArcGIS Tool Reference, 2016). 


\section{REZULTATI}

$\mathrm{Na}$ osnovi analize najdišč v podvelebitskem Primorju smo opredelili šest dominantnih gradišč (slika 4). To so gradišča Kuk v Senju (kataloška številka 1), Gradina v Svetem Juraju (kat. št. 4), Gradina v Starigradu pri Senju (kat. št. 16), Klačnica

Slika 4: Letalski posnetki gradišč v podvelebitskem Primorju.

Figure 4: Aerial photographs of hill forts in sub-Velebit litoral.

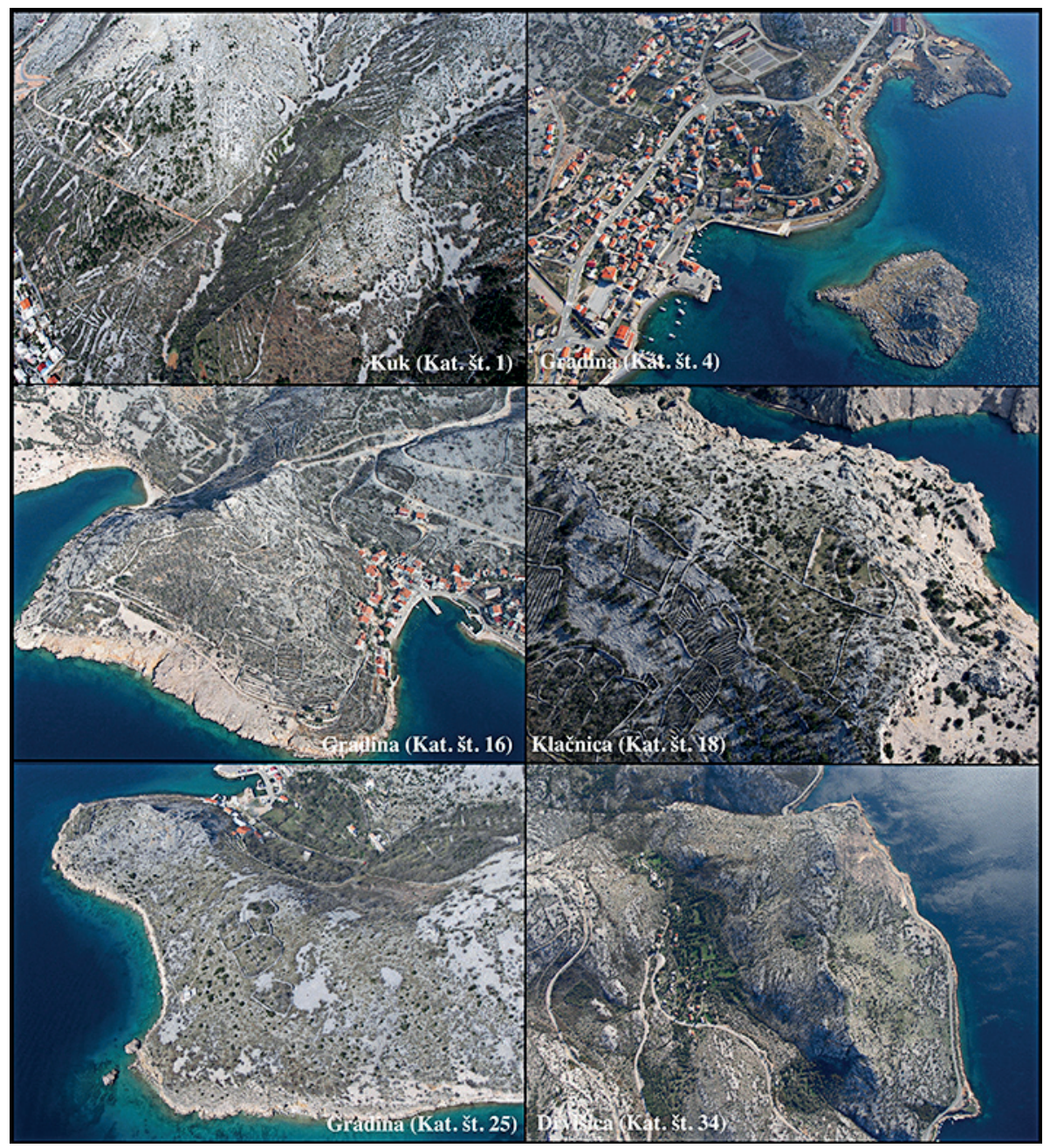

Avtor/Author: V. Glavaš (marec, 2012). 
v Jablancu (kat. št. 18), Gradina v Prizni (kat. št. 25) in Drvišica v Karlobagu (kat. št. 34). ${ }^{1}$ Iz rezultatov analize je razvidno, da so središčna gradišča obravnavanega območja, na katerih je bila zabeležena znatna aktivnost v železni dobi, razporejena na medsebojni oddaljenosti od 3,5 do 4 ure hoje. Ta gradišča so obkrožena z manjšimi gradišči oziroma gradišči manjšega pomena, ki se v grobem nahajajo na robovih ozemelj, ki jih povezuje izohrona 2 uri hoje od centralnega gradišča, ali pa se nahajajo na strateško pomembnih lokacijah.

Slika 5 prikazuje skupnosti, ki so naseljevale severni del obravnavanega območja. Za razliko od ostalih ozemelj se na ozemlju gradišča Kuk v Senju (kat. št. 1) ne nahaja nobeno drugo gradišče manjšega pomena. Razlog za to je lahko nezadostna raziskanost območja. Glede na zadostno količino vode v bližini Kuka, pašnih in obdelovalnih površin v Senjski dragi ter izreden strateški položaj na vozlišču komunikacij proti notranjosti pogorja lahko sklepamo, da se je tu nahajalo le eno gradišče. Na južnem robu gospodarskega zaledja Kuka se nahaja gradišče Torina (kat. št. 2), ki gravitira proti območju gradišča Sveti Juraj. Naravna meja med gradiščem Kuk in južno Gradino v Svetem Juraju je erozijski jarek Vlaška draga, po katerem poteka tudi meja pripadajočih modeliranih gospodarskih zaledij in meja Thiessenovih poligonov teh dveh gradišč.

Modelirano gospodarsko zaledje Gradine v Svetem Juraju (kat. št. 4) zajema 8 gradišč (kat. št. 2, 3, 5, 6, 7, 8, 9, 10). Z modeliranim gospodarskim zaledjem se ujema tudi Thiessenov poligon. Na mejah modeliranega ozemlja se nahajata gradišči Torina na severu in Brinovača na jugu. Na omenjenih gradiščih nismo našli dokazov pomembnejše aktivnosti, zato sklepamo, da sta služili izražanju teritorialnosti. V tem smislu je pozicija Brinovače na južni meji bolj izrazita, saj je zgrajena ob stalnem izviru pitne vode, s čimer je označevala lastništvo izvira. Ostala gradišča na tem ozemlju tudi nimajo naselbinskega značaja. Zgrajena so nad večjimi vrtačami ali ostalimi obdelovalnimi površinami (Glavaši, Čelinka) in nad izviri vode (Čelinka, Brinovača) ter označujejo lastništvo teh virov. Ozemlje skupnosti je bilo lahko, poleg manjših gradišč, izraženo tudi z geomorfološkimi oblikami; na severu s prej omenjeno Vlaško drago, na južnem delu ozemlja pa z globokim erozijskim jarkom Smiljevača.

Naslednje gradišče, ki smo ga definirali kot mesto pomembnejše aktivnosti za rekonstrukcijo gospodarskega zaledja, je Gradina v Starigradu pri Senju (kat. št. 16). Po rekonstrukciji ozemlja se na območju skupnosti nahaja še šest manjših gradišč. Največja gostota slednjih je, kot prikazuje slika 6, na severnem delu na območju današnjega Lukova. Lukovo je zaradi zavetrne lege zaščiteno pred močno burjo in je tako eden najugodnejših zalivov na tem delu Jadranskega morja, tako za plovbo kot za pristajanje oziroma sidranje. V njegovi bližini se nahajajo štiri gradišča kot rezultat označevanja ozemlja. V tem pogledu je najpomembnejše gradišče Klis (kat. št. 11), ki se nahaja na robu ozemlja in s svojo pozicijo ščiti dostop do pitne vode v zalivu Tvrdača. Na drugi strani gradišče Gredina (kat. št. 14) nadzoruje pot preko Ažić Lokve proti Zavižanu (1640 m) in dalje na Velebit. Glede na to, da je bil nadzor te komunikacije zaradi dostopa do virov (les,

1 Gradišče Mali Goljak na Vratniku ni bilo vključeno v končno analizo teritorija, ker se ne nahaja na primorskem pobočju Velebita. Kljub temu smo ga zaradi boljšega prikaza rekonstruiranih teritorijev vključili v kartografske prikaze. 
Rekonstrukcija ozemelj prazgodovinskih skupnosti na prostoru severnega in srednjega Velebita ...

Slika 5: Gospodarska zaledja gradišč skrajnega severnega Velebita.

Figure 5: Site catchments of far northern Velebit mountain hill forts.

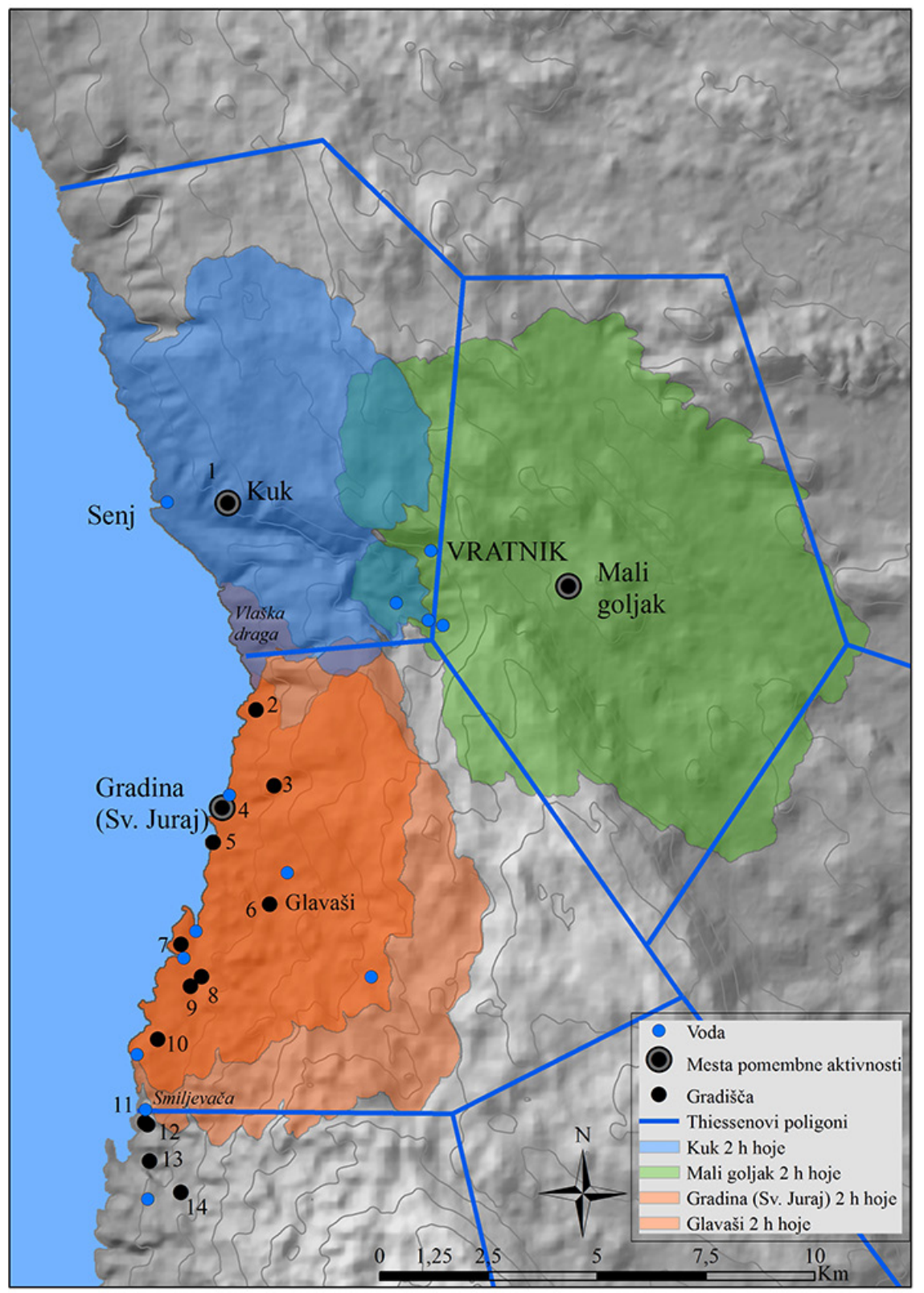

Vir/Source: DGU, 2013. 
Slika 6: Gospodarska zaledja gradišč severnega in srednjega Velebita.

Figure 6: Site catchments of northern and central Velebit Mountain hill forts.

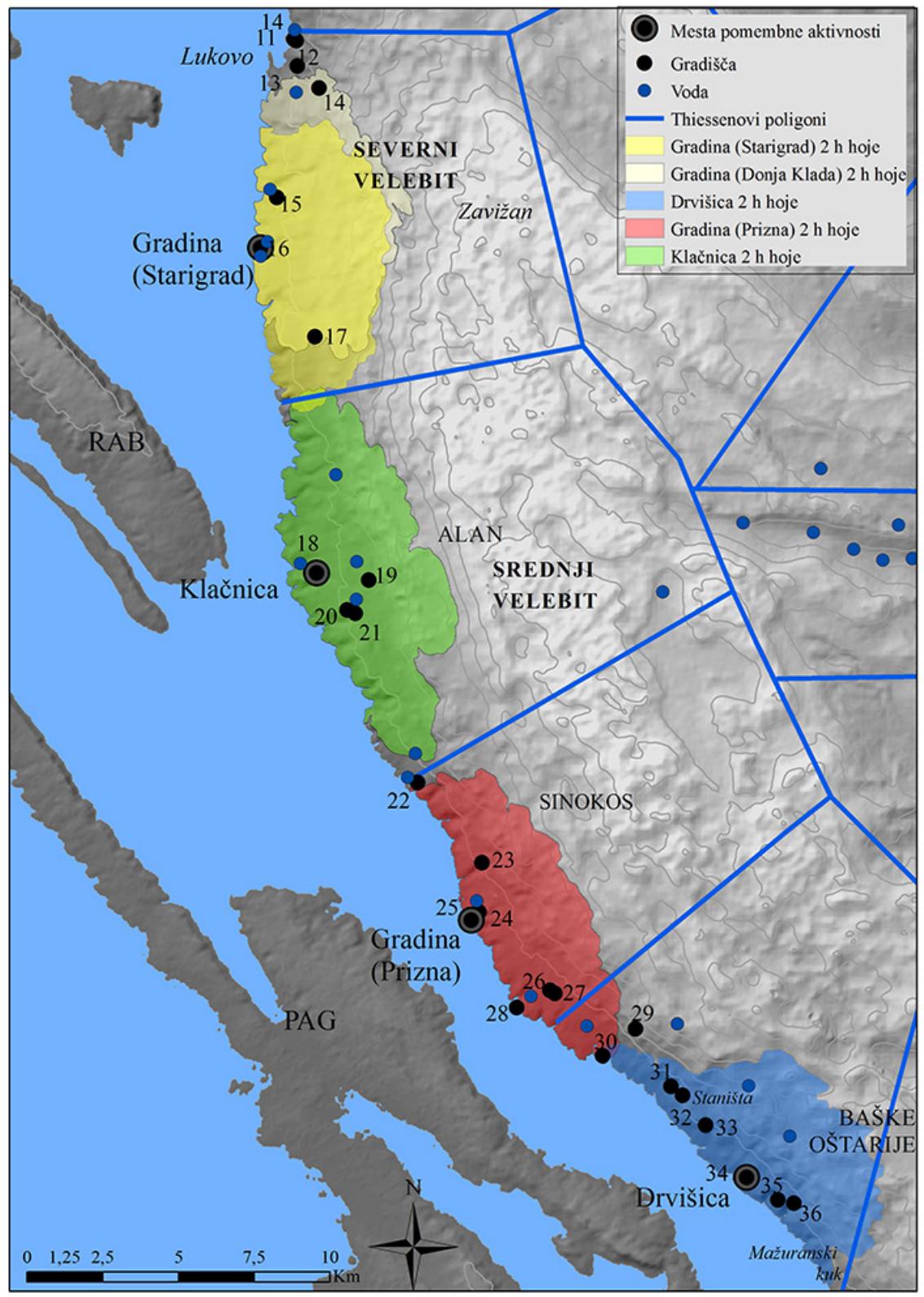

Vir/Source: DGU, 2013. 
planinski pašniki ...) v okviru lastnega ozemlja zelo pomemben, sklepamo, da je Gredina v Ažić Lokvi označevala tradicionalno lastništvo povezave.

Na južnem robu ozemlja ni prisotnih prazgodovinskih gradišč, kar je lahko posledica neraziskanosti ali pa jih tam nikoli ni bilo. Na to kaže izredno dober pregled nad območjem z gradišča Bela kosa (kat. št. 17) proti gradišču Klačnica (Glavaš, 2014). Glede na to, da se Bela Kosa nahaja ob večjih obdelovalnih površinah na območju Ivanče, je bolj verjetno označevala lastništvo pomembnih obdelovalnih površin ter mejnega predela, ki je ekonomsko slabše izkoristljiv.

Skupina gradišč (kat. št. 19, 20, 21), ki se nahaja pod prelazom Alan (1340 m), se združuje v okviru ekonomskega zaledja gradišča Klačnica (kat. št. 18) (slika 6). Gradišča na ozemlju Klačnice ne izkazujejo naselbinskega značaja, opazen pa je zelo dober vizualni nadzor nad velikim območjem, kar lahko pojasnjuje funkcijo teh gradišč. V tem smislu je zelo pomemben nadzor nad potjo, ki vodi proti prevoju Alan, kjer se nahajajo največji pašniki na tem delu Velebita (Glavaš, 2014).

Naslednje gradišče, ki smo ga opredelili kot izhodišče za analizo ozemlja, je Gradina v Prizni (kat. št. 25). Modelirano ozemlje tega gradišča zajema še šest drugih gradišč (slika 6). Na severnem robu se nahaja gradišče Bilančevica u Bačvici (kat. št. 22), ki vizualno nadzira območje v okviru izdelanega Thiessenovega poligona. Glede na obseg razgleda z vrha in nenaselbinski značaj gradišča menimo, da je bila osnovna funkcija gradišča označevanje ozemlja. Na južnem robu ozemlja Gradine v Prizini se nahaja Velika glavica v Cesarici (kat. št. 30) s podobnimi značilnostmi.

Zadnje mesto pomembnejše aktivnosti je Drvišica v Karlobagu (kat. št. 34). V severnem delu se modelirano zaledje gradišča ujema $\mathrm{z}$ mejo pripadajočega Thiessenovega poligona (slika 6). Obrobno gradišče tega območja, ki pripada zaledju Drvišice in je verjetno imelo funkcijo nadzora nad ozemljem, je Perić glavica (kat. št. 29). Razen nadzora nad ozemljem nudi gradišče tudi nadzor nad pomembnimi kali in večjimi obdelovalnimi površinami v Perić Lokvi. Isto vlogo sta imeli gradišči Bojna draga (kat. št. 31) in Tomljenovića glavica (kat. št. 32), ki omogočata nadzor nad potjo ter večjimi obdelovalnimi površinami na območju Staništa. Modelirano ozemlje Drvišice se na jugu zaključuje na območju Mažuranskega kuka, ki je imelo skozi zgodovino in tudi danes vlogo meje katastrskih občin.

\section{RAZPRAVA}

O železnodobnih skupnostih Velebita je dostopnih malo podatkov. Uveljavljeno je mnenje, da so teritorialne občine, ki jih je Rimsko cesarstvo definiralo v 1. stoletju, večinoma odraz predhodnega stanja (Glavičić M., 1997; Dubolnić, 2007). Na podlagi rezultatov te raziskave in prostorskih podatkov je mogoče sklepati, da so podvelebitsko Primorje obravnavanega območja v železni dobi naseljevale manjše skupnosti s središči, zgoščenimi ob morski obali ter pod gorskimi prelazi Vratnik (698 m), Oltari (940 m), Alan (1340 m), Sinokos (936 m) in Baške oštarije (926 m).

Morfološke značilnosti in prostorska razmestitev najdišč nakazujejo možnost obstoja večjega števila železnodobnih središč kot kasneje v antičnem obdobju, ko so na tem 
območju obstajala štiri središča (Senia, Lopsica, Ortopla, Vegium) (Zaninović, 1980). Z analizo smo prepoznali šest gradišč, ki bi lahko delovala kot središča pripadajočih skupnosti. Njihova medsebojna razdalja znaša od 3,5 do 4 h hoje. Ta gradišča se od ostalih razlikujejo po velikosti in debelini struktur ter količini keramičnega materiala na površini. Vsa so, z izjemo gradišča Kuk v Senju, obkrožena z manjšimi gradišči, za katera je značilna majhna količina ali odsotnost keramičnega materiala na površini in manjša količina arheoloških slojev. Ta gradišča imajo svojo funkcijo tudi v pokrajini in teritorialni ureditvi.

Za pokrajino podvelebitskega Primorja sta značilna kraško površje in sušnost, s tem pa tudi skromnost naravnih virov, kot so izviri vode in obdelovalne površine. Slednje so omejene na predele vrtač in ostalih kraških kotanj z debelejšo prstjo. Izkoriščanje zgolj kraških kotanj z debelejšo prstjo $\mathrm{v}$ železni dobi verjetno ni zadostovalo za preživetje, zato so se skupnosti, ki so živele na tem območju, v prvi vrsti ukvarjale z živinorejo. Dodaten vir prihodkov so bile prometne povezave preko Velebita, nad katerimi so izvajali nadzor. Ravno zaradi tega so osrednja gradišča postavljena pod gorskimi prelazi, preko katerih so potekale glavne smeri premikanja dobrin, ljudi ter živine preko pogorja.

Ostala manjša gradišča so zgrajena na območju pomembnih virov preživetja: vrtač, dolcev in izvirov pitne vode. Pri tem je bil ključnega pomena vizualni nadzor nad območji (Glavaš, 2014). Gradišča v bližini virov so praviloma manjša, z morfološkega vidika pa ne dajejo vtisa, da je šlo za v preteklosti stalno naseljene lokacije. Menimo, da sta bili osnovni funkciji gradišč zaščita in nadzor izvirov vode ter obdelovalnih površin, ki so bile navkljub skromnosti ključni dejavnik za obstoj skupnosti. Deloma to dejstvo pripisujemo manjšim pašnim površinam na nižjih nadmorskih višinah kot na vršnem delu pogorja. To zamisel med drugim potrjuje dejstvo, da so vsa gradišča zgrajena nad manjšimi ali večjimi površinami, kjer se nahajajo debelejše prsti, vidne neposredno z gradišč.

Zunanja podoba gradišč ne priča o velikem številu ljudi na obravnavanem območju. Njihova prostorska razporeditev je odraz subsistenčne ekonomije skupnosti, ki je temeljila na živinoreji ter, v omejenem obsegu, tudi poljedelstvu. V okviru svojega ozemlja je imela vsaka skupnost zadostno površino pašnikov za pašo drobnice, zlasti na predelih primorskih pobočij Velebita $v$ zimskih mesecih. Pozno spomladi in poleti so za pašo izkoriščali višje ležeče pašnike.

Mejá v vršnem delu Velebita ne obravnavamo, ker nimamo podatkov o tamkajšnjih arheoloških najdiščih. Verjetno so se ozemlja skupnosti raztezala nekoliko višje, kot je prikazano na slikah 3 in 4 . Menimo, da je bil tudi ta predel strukturiran in razmejen ter da so bila ta območja glede na številčnost izvirov zelo pomembna. Obstaja pa tudi verjetnost, da so bile meje jasneje in ostreje definirane na nižjih predelih, kjer je virov malo. Na višjih predelih predpostavljamo nasprotno situacijo in skupno izkoriščanje pašnih površin zaradi večje razpoložljivosti naravnih virov. Takšna raba prostora je bila potrjena v etnografskih raziskavah (Marković, 1980).

\section{ZAKLJUČEK}

Predmet raziskave je bila rekonstrukcija ozemelj prazgodovinskih železnodobnih skupnosti na primorskem območju Velebita med gorskima prelazoma Vratnik (698 m) in 
Baške oštarije (920 m). Rekonstrukcija ozemelj prazgodovinskih obdobij zelo pogosto predstavlja težavo, saj je materialnih ostankov in dokazov, ki bi neposredno nakazovali na označevanje meja ozemelj, zelo malo. Zaradi tega je bilo osrednje raziskovalno delo usmerjeno v reševanje vprašanja, na kakšen način rekonstruirati ozemlja skupnosti iz obdobja in območja, za katero nimamo neposrednih podatkov, ki bi pričali o obstoju teritorialnosti. Dinamika gibanja je modelirana glede na značilnosti reliefa z uporabo digitalnega modela višin in geografskih informacijskih sistemov. Poleg analize dinamike gibanja smo preučili in z uporabo GIS-ov modelirali tudi druge ključne dejavnike, kot so prostorski odnosi med gradišči, morfološke značilnosti pokrajine ter vidnost posameznih lokacij.

$\mathrm{Z}$ analizo smo določili šest gradišč, ki bi lahko delovala kot središča železnodobnih skupnosti, in jih uporabili kot izhodišča. To so: gradišče Kuk v Senju (kat. št. 1), Gradina v Svetem Juraju (kat. št. 4), Gradina v Starigradu pri Senju (kat. št. 16), Klačnica v Jablancu (kat. št. 18), Gradina v Prizni (kat. št. 25) in Drvišica v Karlobagu (kat. št. 34). Rezultati analiz kažejo na možnost obstoja večjega števila železnodobnih središč kot kasneje v antiki, ko so delovala štiri (Senia, Lopsica, Ortopla in Vegium). Izbrana središča so od sosednjih oddaljena od 3,5 do 4 ur hoje. Od ostalih gradišč se razlikujejo po velikosti, morfološki izvedbi ter debelini struktur in količini arheoloških ostankov na površini.

Struktura teritorialnosti obravnavanega območja je sestavljena iz enega večjega središča in nekaj manjših gradišč, ki se nahajajo v neposredni bližini virov (izvirov vode, vrtač, dolcev). Stalne naseljenosti gradišč ni mogoče dokazati z njihovim videzom in morfologijo. Izstopajoča lastnost, ki jo imajo sekundarna gradišča, je dober nadzor oziroma razgled nad območji virov. Iz tega lahko sklepamo, da je bila osnovna vloga gradišč v ozemeljskem vzorcu označevanje lastništva nad viri.

Skupnosti so si lastile tudi vršni del Velebita, ki ga ne obravnavamo, saj dokazov za obstoj arheoloških najdišč na tem predelu ni. Lahko pa sklepamo, da je selitev skupnosti v višje predele Velebita verjetno potekala med pomladnimi meseci ter trajala do konca poletja zaradi kvalitetnejše paše na planinskih pašnikih. Te selitve presegajo časovni okvir dveh ur hoje od središča in so se verjetno odvijale ciklično, s postopnim pomikanjem proti višjim nadmorskim višinam, v odvisnosti od letnega časa.

Glede na to, da je prostor severnega in srednjega Velebita slabo raziskan, dobljenih rezultatov $\mathrm{v}$ raziskavi ne moremo primerjati s predhodnimi rekonstrukcijami ozemelj prazgodovinskih skupnosti. Predstavljajo pa izhodišče za nadaljnje raziskave gospodarskih zaledij na drugih območjih Velebita. Večina GIS-ov nudi učinkovito in kvalitetno orodje za analizo gospodarskih zaledij, prednosti uporabe pa se odražajo predvsem v hitri in natančni obdelavi velike količine podatkov. Poudariti moramo, da bi kljub temu, da rezultate raziskave ocenjujemo kot dobre, za kvalitetnejšo izvedbo potrebovali bistveno več terenskih podatkov o sami teritorialnosti, o gradiščih, bližini virov in njihovem izkoriščanju ter načinu življenja v prazgodovini. Zaradi tega so možna večja ali manjša odstopanja modeliranih razmejitev od dejanskih razmejitev predantičnih skupnosti. Modeliranje gospodarskih zaledij tako ocenjujemo za primerno pri usmerjanju in odločanju na ravni terenskih raziskav ter nadaljnjem razvoju metod z GIS-i, interpretacije modeliranih ozemelj kot dejanskih ozemelj predantičnih skupnosti pa ne moremo potrditi. 
Preglednica 1: Katalog v članku obravnavanih gradišč.

Table 1: Catalogue of hill forts considered in this article.

\begin{tabular}{|c|c|c|}
\hline $\begin{array}{l}\text { Kataloška } \\
\text { številka } \\
\text { (kat. št.) }\end{array}$ & Ime najdišča & Bližnje sodobno naselje \\
\hline 1 & Kuk & Senj \\
\hline 2 & Torina & Kalić \\
\hline 3 & Samograd & Sveti Juraj \\
\hline 4 & Gradina & Sveti Juraj \\
\hline 5 & Jablanova & Sveti Juraj \\
\hline 6 & Glavaši & Glavaši \\
\hline 7 & Čelinka & Žrnovnica \\
\hline 8 & Zagon & Duboka \\
\hline 9 & Šikinica & Duboka \\
\hline 10 & Brinovača & Seline \\
\hline 11 & Klis & Lukovo \\
\hline 12 & Pod Klisom & Lukovo \\
\hline 13 & Glavčica & Lukovo \\
\hline 14 & Gredina & Ažić Lokva \\
\hline 15 & Gradina & Donja Klada \\
\hline 16 & Gradina & Starigrad kod Senja \\
\hline 17 & Bela kosa & Ivanča \\
\hline 18 & Klačnica & Jablanac \\
\hline 19 & Baričevića glavica & Baričevići \\
\hline 20 & Gradina iznad Smojverske drage & Smojveri \\
\hline 21 & Josinova glavica & Smojveri \\
\hline 22 & Bilančevica & Bačvica \\
\hline 23 & Lavorina & Lomivrat \\
\hline 24 & Kovači & Prizna \\
\hline 25 & Gradina & Prizna \\
\hline 26 & Žuljevača & Trolokve \\
\hline 27 & Žuljevača & Trolokve \\
\hline 28 & Stražbenica & Trolokve \\
\hline 29 & Perić glavica & Perić Lokva \\
\hline 30 & Velika glavica & Cesarica \\
\hline 31 & Bojna draga & Ribarica \\
\hline 32 & Tomljenovića glavica & Staništa \\
\hline 33 & Živi kuk & Karlobag \\
\hline 34 & Drvišica & Karlobag \\
\hline 35 & Đotluša & Đotluša \\
\hline 36 & Paripovica & Đotluša \\
\hline
\end{tabular}




\section{Literatura in viri}

ArcGIS Tool Reference, 2016. Create Thiessen Polygons. URL: http://pro.arcgis.com/en/ pro-app/tool-reference/analysis/create-thiessen-polygons.htm (citirano 19. 2. 2016).

Bintliff, J. L., 1977. Natural Environment and Human Settlement in Prehistoric Greece. BAR Supplementary Series, 28, (ii), 734 str.

Brunšmid, J., 1898. Arheološke bilješke iz Dalmacija i Panonije II. Vjesnik za arheologiju i historiju dalmatinsku, n. s. 3, Split, str. 149-190.

Brunšmid, J., 1899. Arheološke bilješke iz Dalmacije i Panonije II. Vjesnik arheološkog muzeja u Zagrebu, n. s. 3, str. 150-205.

Brunšmid, J., 1901. Groblje brončanoga doba na Klaćenici kod Jablanca (kotar Senj). Povjest mjesta Jablanca. Vjesnik Arheološkog muzeja u Zagrebu, 5, str. 53-62.

Chapman, J., Shiel, R., Batović, Š., 1996. The changing face of Dalmatia: archaeological and ecological studies in Mediterranean landscape. Leicester University Press.

Čače, S., 2006. South Liburnia at the Beginning of the Principate: Jurisdiction and Territorial Organization. Les routes de l'Adriatique antique: Géographie et économie Putovi antičkog Jadrana: geografija i gospodarstvo. Bordeaux, Zadar, Ausonius Mémoire, str. 65-79.

DGU, 2013, podatki izdelani 2015. Digitalni vektorski podatki o nadmorskih višinah RH. Državna geodetska uprava Republike Hrvatske.

Dubolnić, M., 2007. Argyruntum i njegov teritorij u antici. Radovi Zavoda za povijesne znanosti HAZU u Zadru, 49, str. 1-58.

Ducke, B., Kroefges, P. C., 2008. From Points to Areas: Constructing Territories from Archaeological Site Patterns Using an Encanched Xtent Model. V: Posluschny, A., Lambers, K., Herzog, I. (ur.). Layers of perception. Proceedings of the 35th International Conference of Computer Applications and Quantitative Methods in Archaeology (CAA). Berlin, Germany, April 2-6, 2007. Bonn, Dr. Rudolf Habelt GmbH, str. 245-251.

Glavaš, V., 2014 (v tisku). Analize vidljivosti u prapovijesnom krajoliku Velebita. Archeologia Adriatica, 8.

Glavaš, V., Palmer, R., 2013. Aerial and field reconnaissance of Velebit mountain, Aerial archaeology and remote sensing from the Baltic to the Adriatic. Selected Papers of the Annual Conference of the Aerial Archaeology Research Group 13th-15th September 2012, Budapest, Hungary. Budapest, Institute of Archaeological Sciences, Faculty of Humanities, Eötvös Loránd University, str. 19-23.

Glavičić, A., 1966. Arheološki nalazi iz Senja i okolice (I). Senjski Zbornik, 2, str. 383-418.

Glavičić, A., 1967-1968. Arheološki nalazi iz Senja i okolice (II). Senjski Zbornik, 3, str. $5-45$.

Glavičić, A., 1970. Arheološki nalazi iz Senja i okolice (III). Senjski zbornik, 4, str. 45-70.

Glavičić, A., 1980. Arheološki nalazi iz Senja (IV). Senjski zbornik, 8, str. 171-186.

Glavičić, A., 1981-82. Arheološki nalazi iz Senja (V). Senjski zbornik, 9, str. 63-90.

Glavičić, A., 1984. Arheološki nalazi iz Senja i okolice (VI.). Senjski zbornik, 10-11, str. $7-28$. 
Glavičić, M., 1991/92. Željeznodobna i antička naselja podno Velebita. Radovi Filozofskog fakulteta u Zadru, 31, 18, str. 97-119.

Glavičić, M., 1997. Civitas - municipium Lopsica, Radovi Filozofskog fakulteta u Zadru, 35,22 , str. 45-70.

Grlj, A., Glavaš, V., 2015. From hillfort to the mountain pass and back: A comparison of three pathfinding methods. International Interdisciplinary Conference Movements, Narratives and Landscapes, University of Zadar, Zadar, str. 91-92.

Ljubić, Š., 1880. Razne viesti. Vjesnik Arheološkog muzeja u Zagrebu, 2, str. 123-128.

Ljubić, Š., 1889. Crtice iz moga putovanja po južnoj strani gornje Krajine ili gospićkootočke pukovnije. Vjesnik Arheološkog muzeja u Zagrebu, 11, str. 104-109.

Ljubić, Š., 1891. Arheologičko izkapanje u Bagu. Vjesnik Arheološkog muzeja u Zagrebu, 13, str. 97-98.

Marković, M., 1980. Narodni život i običaji sezonskih stočara na Velebitu. Zbornik za narodni život i običaje Južnih Slavena, 48, str. 5-139.

NASA JPL, 2009. ASTER Global Digital Elevation Model. DOI:10.5067/ASTER/ ASTGTM.002.

Novaković, P., 2003. Osvajanje prostora: razvoj prostorske in krajinske arheologije. Ljubljana, Filozofska fakulteta, 294 str.

Stančič, Z., Gaffney, V., 1991. Napovedovanje preteklosti - uporaba GIS v arheološki študiji otoka Hvara. Ljubljana, Znanstveni inštitut Filozofske fakultete, 102 str.

Suić, M., 2003. Antički grad na istočnom Jadranu. Zagreb, Golden Marketing, 527 str.

Štular, B., 2006. Analiza gospodarskega zaledja v arheologiji krajin. GIS v Sloveniji 2005-2006, str. 199-210.

Tobler, W., 1993. Three presentations on geographical analysis and modeling. 1) Non-isotropic modeling, 2) Speculations on the geometry of Geography 3), Global spatial Analysis. National Center for Geographic Information and Analysis, Technical Report, str. 93-101.

Vita-Finzi, C., Higgs, E., 1970. Prehistoric economy in the Mount Caramel area of Palestine: site catchment analysis. Proceedings of the Prehistoric Society, 36, str. 1-37.

Zaninović, M., 1980. Antička naselja ispod Velebita, Senjski zbornik, 8, str. 187-196.

\section{GIS BASED RECONSTRUCTION OF THE PREHISTORIC COMMUNITIES' TERRITORIES OF NORTHERN AND CENTRAL VELEBIT MOUNTAIN (CRO)}

\section{Summary}

The research problem presented in this article is the reconstruction of territories of the prehistoric Iron Age communities in the coastal area of northern and central Velebit Mountain. The study area is limited to the area between mountain passes Vratnik and Baške oštarije. Reconstructions of prehistoric territories can be problematic because the material remains and evidence directly pointing at the marking of the borders are scarce. 
Therefore, the focus of this research is a reconstruction of territorial behavior in a period and in an area where direct data pointing to such behavior is completely lacking. Movement in this work is modeled according to the characteristics of the terrain through the use of digital elevation model and geographic information systems. In addition to the analysis of movement we also examined other factors that are critical to reconstruction such as spatial relationship between the forts, morphological characteristics of the landscape, and visibility of individual locations. These factors were also modeled using GIS.

Six hill forts were identified as possible Iron Age centers by our analysis. These six hill forts - hill fort Kuk in Senj (cat. no. 17), hill fort Gradina in the Sveti Juraj (cat. no. 30), hill fort Gradina in Starigrad near Senj (cat. no. 6), Klačnica in Jablanac (cat. no. 11), hill fort Gradina in Prizna (cat. no. 15) and Drvišica in Karlobag (cat. no. 9) - were used as starting points for the reconstruction of territories. Analytical results indicate a possibility of the existence of a larger number of Iron Age centers as there were later in antiquity when there were four centers (Senia, Lopsica, Ortopla and Vegium). Neighboring centers are located at distances corresponding to 3.5 to 4 hours of walking from each other. Other hill forts (whose territories were not reconstructed) are different from the major ones in size, morphology, the size of structures, and the amount of scattered findings.

Territoriality structure for the area in question consists of one major center and several smaller fortified positions that are located in the immediate vicinity of exploitable resources (water springs, dolines and dells). Permanent settlement of these hill forts can not be proven. Also, this cannot be deduced from their appearance and morphology. Secondary hill forts are characterized by good control of the exploitable resources. Control of these resources and marking of ownership may have been the primary function of secondary hill forts.

We assume that the communities were also exploiting the upper parts of the Velebit Mountain which are not subject of this research as there is no archeological evidences or traces from that period in the area. Relocation of communities in higher areas of Velebit is likely to have taken place during the spring and summer months due to significantly higher quality mountain pastures. These movements exceed the time frame of two hours' walk from the central hill fort and are likely to take place progressively by gradually moving towards higher altitudes, depending on the season.

Given that the area of the northern and middle Velebit is very poorly studied, the results obtained in this research cannot be compared with previous reconstructions of the prehistoric communities' territories. They represent a starting point for further research of the territoriality in other areas of Velebit Mountain and elsewhere.

(Translated by the authors) 